\title{
Kearifan Lokal Penguasa Daerah Menghadapi Liberalisasi Pendidikan "Upaya Kota Yogyakarta Meningkatkan Kualitas Pendidikan"
}

\section{Herry Zudianto}

The local government of Yogyakarta in increasing and maintaining the competitive advantage and as the centre city of education is building supporting macro factors: layout, public education fasilities, regulation, and image (opini). Beside the factors ebove mention, in accordance with the outhority of city local government of Yogyakarta has made the effort to apply the quality education realization based on four indicators, those are the graduation quality, the quality of teaching and learning process, the quality of school service, and that of school atmosphere.

Kata Kunci: kearifan lokal, peguasa daerah, liberalisasi, pendidikan

Deranan manusia menduduki posisi yang penting, selain berfungsi sebagai subjek tetapi sekaligus sebagai objek. Sebagai subjek, manusia dituntut untuk dapat berperan sebagai khalifatullah yang dapat berperan optimal di dunia. Sebagai objek, setiap aktivitas yang dilakukan oleh siapapun di muka bumi sudah seharusnya bertujuan meningkatkan kesejahteraan manusia. Dalam konteks demikian upaya peningkatan kualitas sumber daya manusia mutlak harus dilakukan. Salah satu pihak yang memiliki peranan penting dalam peningkatan kualitas sumber daya manusia adalah pemerintah, dalam hal ini termasuk pula Pemerintah Kota Yogyakarta.

Upaya peningkatan kualitas sumber daya manusia dapat dilaksanakan melalui berbagai sektor, tetapi sektor terpenting adalah melalui pendidikan, meliputi kognitif, afektif dan psikomotorik. Yang berarti bahwa pendidikan tidak hanya akan menghasilkan manusia yang cerdas, tetapi juga bermoral dan memiliki ketrampilan.

Untuk mewujudkan keberhasilan peningkatan kualitas sumber daya manusia melalui sektor pendidikan tersebút tidaklàn mudah diperlukan keterlibatan seluruh stakeholders, lebih-lebih pada kondisi saat dunia memasuki era globalisasi dan liberalisasi. Untuk itu menjadi penting bagi seluruh stakeholders di Propinsi DIY untuk mengkaji ulang kebijakan pembangunan sektor pendidikan dalam menghadapi perubahan lingkungan yang demikian cepat.

\section{Predikat Kota Pendidikan}

Salah satu predikat yang disandang Kota Yogyakarta adalah sebagai Kota Pendidikan. 
Predikat tersebut disandang karena, pertama, banyaknya lembaga pendidikan berada di Kota Yogyakarta, sejak dari Pra TK sampai Perguruan Tinggi. Data dari Yogyakarta Dalam Angka Tahun 2004 jumlah lembaga pendidikan Pra TK dan Tk sebesar 206 unit, SD 221 unit, SMP 66 unit, SMU 56 unit, SMK 30 unit dan Perguruan Tinggi 50 unit. Kedua, Kota Yogyakarta juga memiliki berbagai lembaga pendidikan dan pelatihan dalam bentuk lembaga pendidikan dan ketrampilan (LPK) yang menyediakan fasilitas pendidikan dan pelatihan yang relatif mudah diterima pasar, antara lain LPK Komputer, LPK Perhotelan, LPK Sekretaris Perkantoran dan sebagainya. Ketiga, pelajar dari seluruh daerah di Indonesia menimba ilmu di Kota Yogyakarta. Keempat, berdasarkan persepsi masyarakat dari luar, mutu/kualitas lulusan yang dihasilkan dari lembaga pendidikan di Yogyakarta memiliki kelebihan dibandingkan dengan daerah lain. Kelima, Dukungan budaya masyarakat Yogyakarta yang terbuka dan dapat menerima perubahan, setiap pendatang diposisikan sebagai tamu yang pantas dihormati.

\section{Peran Kota Yogyakarta dalam Peningkatan Daya Saing Pendidikan}

Predikat tersebut di atas tentunya membanggakan bagi setiap warga Kota Yogyakarta, dan juga sektor pendidikan menjadi salah satu utama lokomotif perekonomian Kota Yogyakarta. Tetapi selama ini kita agak terlena dengan predikat tersebut, kita lupa untuk selalu memiliki kreativitas dan sinergitas dalam mengembangkan pendidikan.. Beberapa wilayah di luar DIY telah mengembangkan potensinya di sektor pendidikan, antara lain Bandung dan Malang. Hal tersebut juga dipercepat dengan adanya otonomi daerah, sehingga berbagai daerah berupaya untuk mengembangkan sektor pendidikan. Dampak yang terasa terutama pada pendidikan tinggi, sudah hampir tiga tahun hampir sebagian besar perguruan tinggi di DIY mengalami masa penurunan, setelah sebelumnya menikmati masa pertumbuhan dan kedewasaan. Dampak tersebut akan semakin terasa dengan semakin derasnya proses globalisasi, termasuk globalisasi pendidikan. Menghadapi kecenderungan tersebut di atas, kita merasakan belum ada langkah nyata dan sinergis dariseluruh sektor pendidikan untuk mendapatkan solūsi terbaik.

Peran Pemerintah Kota Yogyakarta dalam rangka meningkatkan dan mempertahankan daya saing serta predikat sebagai Kota Pendidikan sebagai lembaga publik adalah dengan membangun faktorfaktor pendukung makro, antara lain tata ruang, fasilitas publik pendidikan, regulasi dan membangun opini. Selain faktor-faktor pendukung makro tersebut, dan sesuai dengan kewenangan yang dimiliki Pemerintah Kota Yogyakarta telah berupaya, antara lain, pertama penyelenggaraan pendidikan yang berkualitas yang didasarkan pada empat ukuran/indikator, yaitu (1) mutu produk/ Iulusan, (2) mutu proses pembelajaran, (3) mutu layanan sekolah dan (4) mutu lingkungan sekolah. Kedua, pemberian block grant, block grant yang bersifat umum dan khusus diberikan kepada sekolah sejak SD sampai dengan SMU/SMK. Ketiga, pemberian bea siswa, untuk mendukung komitmen/ kebijakan bahwa tidak ada anak usia sekolah di Kota Yogyakarta yang tidak bersekolah karena alasan ekonomi atau semua anak usia sekolah harus bersekolah. Keempat, pembangunan Taman Pintar, konsep taman pintar adalah sebagai ruang publik tempat masyarakat berekreasi sambil belajar. Disini pula pelajar dapat mengembangkan 
aspek kognitif, psikomotorik maupun afektif. Kelima, pengembangan sekolah internasional, untuk menjawab proses globalisasi termasuk di dunia pendidikan. Keenam, pengembangan kreatifitas dan inovasi guru dalam proses belajar mengajar, untuk mendorong dan memfasilitasi guru dalam membuat alat peraga sehingga dapat mempermudah proses belajar mengajar.

Dalam Rencana Tata Ruang Wilayah Kota Yogyakarta pemerintah telah menetapkan beberapa kawasan yang dapat dikembangkan sebagai fasilitas pendidikan beserta penunjangnya. Upaya ini tentunya harus pula sinergis dengan upaya serupa yang dilakukan oleh Pemerintah Kabupaten Sleman dan Kabupaten Bantul. Sinergitas tersebut lebih dititik-beratkan pada fungsi masing-masing kabupaten dan kota dalámmendukung pengembangan pendidikan, dikaitkan dengan penataan ruangnya.

Untuk menjaga mutu pendidikan Pemerintah Kota akan selalu berupaya mengoptimalkan fungsi prasarana pendidikan dan pendukungnya serta manajemen penyelenggaraan pendidikan. Upaya ini ditempuh dengan perbaikan sekolah dan pelatihan manajemen pengelolaan sekolah.

Pada aspek regulasi, amanat UU Sistem Pendidikan untuk mengalokasikan $20 \%$ dari APBD pada bidang pendidikan, Pemerintah Kota Yogyakarta sudah dapat dipenuhi pada tahun 2006 ini. Kemudian Pemerintah Kota Yogyakarta juga akan mendorong dan memfasilitasi stakeholders pendidikan yang dilembagakan daiam Dewan Pendidikan Kota dapat berperan lebih optimal dalam menjembatasi berbagai kebutuhan untuk pengembangan pendidikan di Kota Yogyakarta.

Dalam rangka memperkuat lingkungan, dan mendukung sektor pendidikan, Pemerintah Kota Yogyakarta telah menetapkan: Perda Pondokan. Perda ini mewajibkan setiap rumah pondokan memiliki induk semang dan dukungan lingkungan sekitar pondokan, sehingga tujuan belajar di Kota Yogyakarta dapat dicapai. Berdasarkan hasil identifikasi, ketiadaan induk semang memicu terjadinya berbagai penyimpangan di rumah pondokan. Untuk mengoptimalkan Perda tersebut, maka Pemerintah Kota Yogyakarta bersama dengan berbagai stakeholders mendirikan kost crisis centre, yaitu sebuah lembaga yang diharapkan dapat menjembatani kebutuhan pelajar di wilayah di satu pihak dan kebutuhan wilayah di lain pihak. Selain itu melalui kost crisis centre penyimpangan dini di rumah pondokan dapat diketahui secara dini, sehingga akan mempercepat tidak lanjut upaya mengatasinya. Berkaitan dengan isu narkoba yang semakin meningkat di Kota Yogyakarta sehinggatelah dibentukBadan Penanggulangan Narkotika. Secara berkala badan ini berdiskusi dan menjalin kemitraan dengan berbagai lembaga pelajar untuk mengurangi penyalahgunaan narkotika.

Pada aspek membangun opini, Pemerintah Kota Yogyakarta dalam berbagai kesempatan pameran dagang dan kunjungan ke dalam dan luar negeri, selalu menampilkan potensi bidang pendidikan. Upaya ini diharapkan dapat memberikan informasi yang komprehensif kepada masyarakat yang akan menempuh pendidikan di Kota Yogyakarta. Demikian pula hampir setiap kerjasama dengan daerah lain baik dalam negeri maupun luar negeri, salah satu aspek yang dikerjasamakan adalah bidang pendidikan. Untuk mengoptimalkan upaya tersebut juga didukung dengan pertukaran pelajar antara daerah. Dengan pertukaran pelajar secara tidak langsung informasi tentang potensi pendidikan di Kota Yogyakarta jüga akan tebih komprehensif. 
Topik: Globalisasi dan Liberalisasi dalam Bidang Pendidikan

\section{Penutup}

Tantangan Liberalisasi Pendidikan akan sangat berpenganuh pada penyelenggarakan pendidikan di DIY. Kota Yogyakarta sudah berupaya dapat mempertahankan dan selalu memperbaharui predikat sebagai kota pendidikan. Tetapi upaya tersebut belum optimal jika tidak ada sinergi antara berbagai stakeholders. Pemerintah Kota Yogyakarta berharap melalui fasilitasi Pemerintah Propinsi DIY, kita dapat merumuskan kembali dan langkah nyata upaya untuk mempertahankan predikat kota pendidikan.Sinergi antar perguruan tinggi baik negeri dan swasta perlu ditingkatkan dengan memperjelas fungsi dan peran masing-masing perguruan tinggi untuk mengantisipasi liberalisasi pendidikan.

\section{Daftar Pustaka}

Peraturan Daerah Nomor 1 Tahun 2006 tentang Anggaran Pendapatan dan Belanja Daerah Kota Yogyakarta Tahun Anggaran 2006.

Peraturan Daerah Nomor 13 Tahu 2004 tentang Pola Dasar Pembangunan Daerah Kota Yogyakarta Tahun 20022006.

Peraturan Daerah Nomor 15 Tahun 2004 tentang Rencana Strategik Daerah Kota Yogyakarta Tahun 2002-2006.

Undang Undang Nomor 20 Tahun 2003 tentang Sistem Pendidikan Nasional.

-Yogyakarta Dalam Angka Tahun 2005. 